\title{
Darnaus darbo vietų vystymo kaimiškuose regionuose teorinès prielaidos
}

Vytautas Pilipavičius

Aleksandro Stulginskio universitetas, Universiteto g. 10,

LT-53361, Akademija, Kauno r.

El.paštas:vpilipavicius@gmail.com
Svarbi reikšmė Lietuvos kaimo plètros procese šiandien teikiama kaimiškujų regionų vystymui, kuris grindžiamas darniu darbo vietų kūrimu, stiprinančiu kaimo vietovių konkurencingumą.

Straipsnyje analizuojamos darnaus sampratos vystymo ištakos bei raida, apžvelgiami teoriniai darbo vietų vystymo aspektai bei analizuojama darnaus darbo vietų vystymo kaimiškuose regionuose problematika. Atliktos analizès pagrindu parengtas darnaus darbo vietų vystymo kaimiškuosiuose regionuose koncepcinis modelis.

Rengiant straipsnį naudotasi surinkta mokslinių tyrimų medžiaga vykdant Lietuvos mokslo tarybos patvirtintą projektą „Darnus ir subalansuotas darbo vietų vystymas kaimiškuose regionuose" (pagal nacionalinę mokslo programą „Socialiniai iššūkiai nacionaliniam saugumui").

Raktažodžiai: darnus vystymas, darbo vietų vystymas, kaimiškųjų regionų vystymas

\section{IVADAS}

Lietuvos Nacionalineje darnaus vystymosi strategijoje (Nacionalinè darnaus..., 2009) darni plètra siejama su: nuosaikiu ir suderintu tarp ūkio šakų ir regionų ekonomikos vystymu; skirtumų tarp regionų gyvenimo lygio išlyginimu išsaugant jų savitumą; ūkio poveikio aplinkai mažinimu; efektyvesniu gamtos išteklių naudojimu ir atliekų tvarkymu; pavojaus žmonių sveikatai mažinimu; pasaulinès klimato kaitos ir jos pasekmių švelninimu; efektyvesne biologinès ịvairovès apsauga; kraštovaizdžio apsauga ir racionaliu tvarkymu; nedarbo, skurdo ir socialinès atskirties mažini$\mathrm{mu}$; švietimo ir mokslo vaidmens didinimu; kultūrinio savitumo išsaugojimu.

Lietuvoje žemès ūkio ir kaimo plètra (Lietuvos kaimo pletros..., 2007) numatoma per investicijas $\mathfrak{i}$ ūkius, jų modernizavimą ir veiklos ịvairinimą, kokybiškų produktų gamybos pletrą ir rinkodarą, užimtumo didinimą skatinant alternatyvią veiklą ir socialinès būklès gerinimą, kaimo atnaujinimą ir infrastruktūros plètrą bei aplinkosaugą ir racionalų gamtos išteklių naudojimą. Kaimiškųjų regionų ir kaimo vietovių plètra darnaus vystymosi kontekste akademineje bendrijoje analizuota tiek užsienio (McConnell, Brue, 1986; Young, 1991; Ciani, 1998; Brandbury, Clair, 1999; Nattrass, Altomare, 1999; Brandbury, 2000; Ott, 2003; Gercheva, 2005; Hasna, 2007; Skydan, 2008; Philip, Berke, Marija, 2010 ir kt.), tiek Lietuvos (Čepinskis, Smilga, 2002; Mačys, 2006; Bivainis, Tamošiūnas, 2007; Juknys, 2007; Čiegis, Ramanauskiené, Martinkus, 2009; Baležentis A., Baležentis T., 2010 ir kt.) mokslininku darbuose. Kiti Lietuvos mokslininkai (Treinys, Baležentis, 1999; Čaplikas, Michailovaitè, 2003; Ziminienè, 2008; Vitunskienè, 2009; Žukovskis, 2009; Aleksandravičius, 2010; Vaznonis, Čiūtaitè, 2010) kaimo vietovių vystymą analizavo ir vertino pagal ES ir Lietuvos strateginio planavimo dokumentus, užimtumą arba politikos priemonių poveiki užimtumui. Poveiki užimtumui, analizuojant darbo rinkos struktūrą, 
sudèti, funkcionavimo galimybes, procesus ir juos formuojančius veiksnius, tyrè P. Krugman, M. Obstfeld (1991); F. Mayer (1991); P. Wonnacott, R. Wonnacott (1994); P. Jones, C. Osterweil, D. Whitehead (1996); B. Martinkus, A. Savanevičienè (1996); V. Navickas, K. Paulavičius (1999); B. Martinkus, D. Beržinskienė (2005); D. Ghai (2006); G. Mačys (2006); B. Gruževskis, V. Gražulis (2008); J. Moskvina (2008); A. Simanavičienè, L. Užkurytè (2009) ir kt. Žmogiškųjų išteklių reikšmes, turinčias įtakos gyventojų užimtumui bei darbo rinkos politikai, darbo jegos paklausą ir pasiūlą (analizuojant techninès pažangos bei globalizacijos procesų lemiamus veiksnius) tyré P. Krugman, M. Obstfeld (1991); B. Nattrass, M. Altomare (1999); D. Brown (2002); G. Bosworth (2006); W. Patton, M. McMahon (2006).

Nors Lietuvos mokslo erdvèje ir didejja dèmesys darbo rinkos ir užimtumo politikos analizei bei vertinimo problematikai, deja, politikos tikslų, uždavinių bei priemonių poveikis darniam darbo vietų vystymui kaimo regionuose kol kas nematomas.

Darnus darbo vietų vystymas kaimiškose vietovèse - vienas iš svarbiausių uždavinių igyvendinant Europos Sąjungos ir Lietuvos žemès ūkio bei kaimo plètros strategines nuostatas.

Straipsnyje analizuojama mokslinè problema, kuri formuluojama klausimais:

1. Kas sudaro teorines darbo vietų vystymo prielaidas?

2. Kas lemia darnų darbo vietų vystymą kaimiškuose regionuose?

Tyrimo objektas - darnus darbo vietų vystymas kaimiškuose regionuose.

Tyrimo tikslas - parengti darnaus darbo vietų vystymo kaimiškuose regionuose koncepcini modeli.

\section{Uždaviniai:}

1. Išnagrinèti darnaus vystymo sampratos raidą bei išryškinti teorines darbo vietų vystymo prielaidas.

2. Parengti darnaus darbo vietų vystymo kaimiškuose regionuose koncepcini modeli.

\section{METODAI IR SALYYGOS}

Pagal mokslinių tyrimų ir eksperimentinès plètros standartus (Frascati..., 2002) vykdyti tyrimai, priskirtini taikomiesiems moksliniams tyrimams, skirtiems idejų ir koncepcijų formulavimui, modelių kūrimui ir pritaikymui praktikoje. Tyrimams atlikti naudoti šie mokslinio tyrimo metodai:

- dokumentinių šaltinių analizè - tai ES ir Lietuvos programinių nuostatų analizé, leidusi atskleisti darnaus vystymo kiltis bei raidą;

- mokslinių tyrimų turinio (Contents) analizé - tai sisteminé mokslinių tekstų, teorinių teiginių, dėsnių ar dėsningumų turinių analizé, leidusi išryškinti teorines darbo vietų vystymo prielaidas;

- sisteminimas ir sintezè - tai teorinių prielaidų ir programinių jžvalgų gretinimas, leidęs parengti koncepcini darnaus darbo vietų vystymo kaimiškuose regionuose modelį.

\section{REZULTATAI IR JŲ APTARIMAS}

\section{Darnaus vystymo sampratos ištakos}

Darnaus vystymo idejos ištakos turi istorines šaknis, tačiau darnaus vystymo koncepcija ypač aktuali tapo XX a. Tai lėmé mokslo ir technikos pasiekimai, sudarę galimybę rankų darbą keisti mechanizuotu darbu, sukūrę prielaidas gamybos plètrai, jos koncentracijai ir industrializacijai.

Septinto dešimtmečio pabaigoje buvo suvokta, kad toks gamybos intensyvumas ir progresas, kuris grindžiamas pertekline gamyba, neracionaliu gamtos išteklių naudojimu, veda prie aplinkos užterštumo, daro didelę žalą gamtai bei žmonijai.

Apie galimas ekologinès katastrofos pasekmes rimtai pradèta diskutuoti $1968 \mathrm{~m}$. Romos klube, prabilta apie darnaus vystymo sąvoką. $1972 \mathrm{~m}$. Stokholme buvo sukviesta pirmoji Jungtinių Tautų konferencija aplinkos ir vystymo klausimais.

Darnaus vystymo sąvoka pirmą kartą oficialiai pateikta $1980 \mathrm{~m}$. trijų tarptautinių institucijų - Tarptautinès gamtos apsaugos sąjungos (IUCN), Jungtinių tautų aplinkos programos (UNEP) ir Laukinès gamtos fondo (WWF) paskelbtame dokumente - Pasaulio apsaugos strategija (World Conservation Strategy...), kuris padejo darnaus vystymo koncepcijos pagrindus. Puoselèjant šią idèją, $1987 \mathrm{~m}$. Brundlando (Brundland...) ataskaitoje buvo pateiktas darnaus vystymo igyvendinimo planas. Darnaus vystymo koncepcijos pagrindinès nuostatos XXI a. buvo suformuotos 1992 m. Rio de Žaneiro darbotvarkeje. 
Pagrindiniai akcentai - darnaus vystymo ugdymo svarba ir reikšmé, kompetencijų didinimas bei kvalifikacijos kèlimas (Darbotvarkè 21...).

Vèliau darnaus vystymo sąvoka naudojama svarstant Europos miestų tolydžios plètros (Olborgo chartija...) bei Europos Sajungos vystymo strategijas.

Daug mokslinių diskusijų kyla dèl darnaus vystymo sąvokų vartojimo lietuvių kalboje. Anglu kalboje darnus vystymas tapatinamas su Sustainable development sąvoka. Lietuvos mokslinès literatūros terminologijoje Sustainable development apibūdinama kaip darnus vystymasis, subalansuotas vystymas, tausojanti plètra, subalansuotas vystymas / subalansuota plètra ir pan. Lietuviški terminai darnus ir subalansuotas anglų kalboje turi šiuos atitikmenis:

- darnus - regular, harmonious, proportioned, accordant - reguliarus, taisyklingas, dèsningas; harmoningas, proporcingas, atitinkantis, darnus;

- subalansuotas - balanced, well-balanced - išlaikantis pusiausvyrą, ramus, racionalus, apgalvotas, protingas, subalansuotas.

Tad darnus ir subalansuotas terminai kartu atitinka Sustainable sąvoką, kur Sustainable - išlaikantis pusiausvyrą, vykstantis nuosekliai, pastoviai. Todèl straipsnyje naudojama tik darnaus vystymo sąvoka.

Didžioji dalis mokslo atstovų pažymi, kad darnus vystymas yra nesibaigiantis procesas, tai nèra kažkokios stabilios ir nekintamos būsenos siekimas, tai - kaitos procesas ir gali būti apibūdintinas kaip tam tikrų savybių kaita:

- augimas - nulemiantis vidinius ir išorinius kiekybinius bei kokybinius pokyčius;

- diferenciacija - individualių vystymosi dèmenų išryškẻjimas;

- struktūrizacija - atskirų dèmenų sujungimas $\mathfrak{i}$ derinius, reiškiančius daugiau negu dèmenų sumą;

- centralizacija - veiksmų valdymo sugriežtinimas numatant konkrečius vystymo tikslus;

- integracija - kokybinis pasikeitimas, veikimo igūdžiu jungimas ị prasmingą seką ir derinius;

- branda - geresné nūdienos ir ateities kartuc gyvenimo kokybè, garantuojanti ekonominio, socialinio, aplinkosaugos ir kultūrinio vystymosi dermę.
Darnaus vystymo sampratos ištakų analizè rodo, kad darnumo ir subalansuotumo sąvokos neturi griežtos takoskyros ir dažnai tapatinamos arba pakeičiamos viena kita. Todèl straipsnyje darnus ir subalansuotas vystymas bus naudojamos kaip vienas kitą papildantys sinonimai, kaip sisteminè charakteristika, leidžianti analizuoti darbo vietų vystymą visumos požiūriu.

\section{Darbo vietu vystymo teoriniai aspektai}

Darbo vietų vystymas neatsiejamai susijęs su ūkine veikla integruotoje ekonominejje ūkio struktūroje. Ekonomikos mokslas ūkinę veiklą apibrěžia kaip ūkinių vienetų, tarpusavyje susijusių gamybiniais, vartojimo, mainų, finansiniais ir kt. ryšiais, sistemą, kaip gamybos ir vartojimo veiklų tarpusavio sąveiką, kaip gamybinių santykių, atitinkančių tam tikrą visuomenès gamybinių jègų raidos lygí, visumą ir pan. Pati ūkinè veikla, kaip ūkinių vienetų tarpusavyje susijusių ryšių sistema, priklauso nuo organizacijos vystymo ir veiklų tarpusavio sąveikos derinimo integracijos kontekste. Todèl teoriniai darbo vietu vystymo tyrimai turi du analizès aspektus:

- darbo vietu vystymas organizacijoje - lemia darbo vietos ir darbo jejgos santyki organizacijoje;

- darbo vietų vystymas teritoriniu požiūriu - lemia ekonominès veiklos ir organizacijos vystymo santyki darbo rinkoje.

Vadybiniu požiūriu darbo vieta - tai tam tikrą funkciją organizacinèje struktūroje užtikrinantis elementas, kurio funkcionalumą lemia darbo jèga, o darbo vietos reglamentavimą - vidiniai ir išoriniai veiksniai. Vidiniams veiksniams priskirtinas pareigybinis, technologinis ir administracinis, išoriniams - politinis, teisinis ir saugos reglamentavimas.

Darbo jejgos reglamentavimą lemia darbuotojo kompetencijos, kurias nusako išsilavinimas, kvalifikacija, įsipareigojimas ir atsakomybè. Darbo vietos aprūpinimas darbo jèga fiksuojamas darbo sutartimi (1 pav.).

Darbo vieta ir darbo jèga sudaro funkcini elementą organizacinejje struktūroje, reikalingą organizacijos veiklai vykdyti. Organizacinès struktūros funkciju pobūdi lemia organizacijos veikla(os), kurią (ar kurias) ji vykdo. Todèl darbo vietų vystymas susijęs su veiklos funkcionavimo užtikrinimu, veiklų diversifikavimu bei veiklų integravimu. 


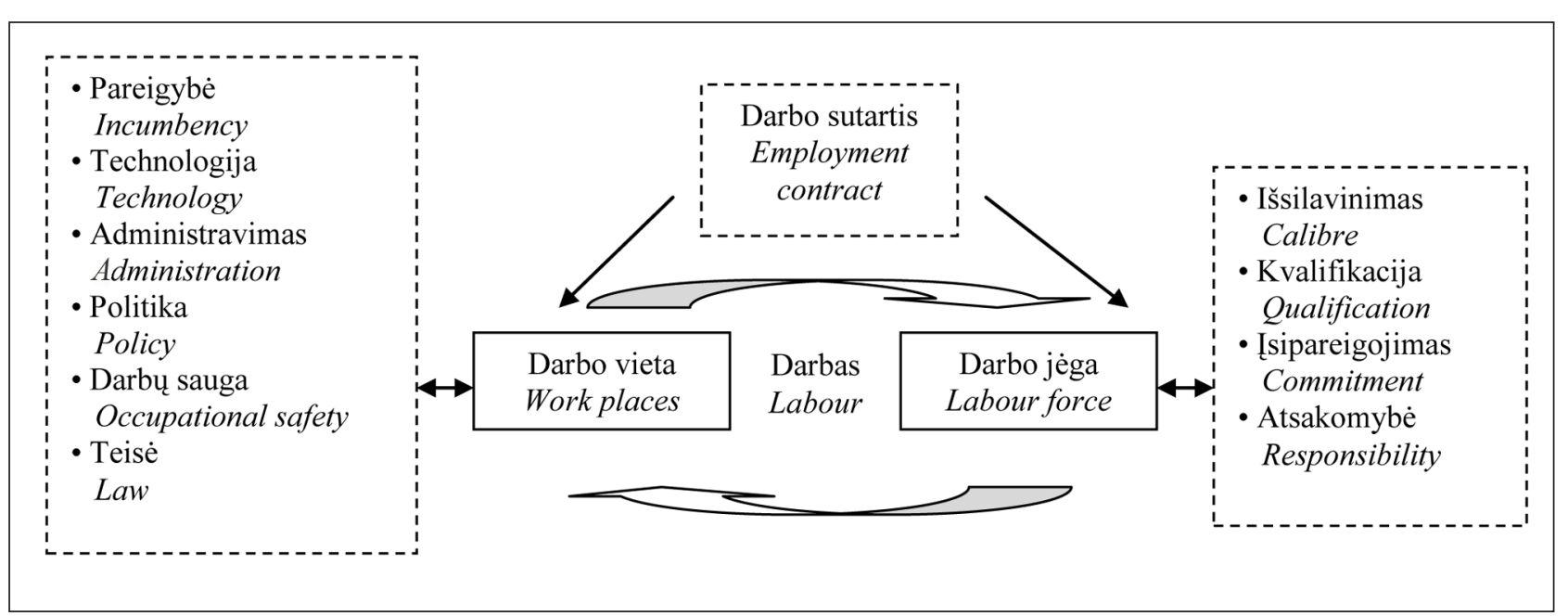

1 pav. Darbo vietos ir darbo jègos santykis (parengta autoriaus)

Fig. 1. A ratio of work places and labour force (prepared by the author)

Moksliniuose tyrimuose (Martinkus ir kt., 1996; Navickas ir kt., 1999; Martinkus ir kt., 2005; Bosworth, 2006 ir kt.) darbas apibrèžiamas kaip sąmoninga protinè ar fizinè veikla, kurios rezultatas - sukurtas produktas. Reikalavimai produkto kokybei lemia darbo jègos atitikimą darbo vietai, o produkto ar paslaugos reikmé rinkoje - darbo jejgos paklausos ir pasiūlos santyki organizacijoje. Todèl darbo vietų vystymas organizacijoje priklauso nuo strateginių tikslų igy- vendinimo, integruojantis $\mathfrak{i}$ aplinką, o darbo jègos pasiūlos ir paklausos santykị lemia produkto ar paslaugos reikmè ir kokybė rinkoje bei darbo jègos kvalifikaciju atitikimas darbo vietai, garantuojantis organizacijos veiklos kokybinius ir kiekybinius rezultatus (2 pav.).

Darbo vietų vystymą organizacijoje lemia darbo jègos ugdymas. Tai susijęs su mokymu ir kvalifikacijos kèlimu, sudaro galimybes darbuotojo karjeros perspektyvai. Dabuotojo karjeros

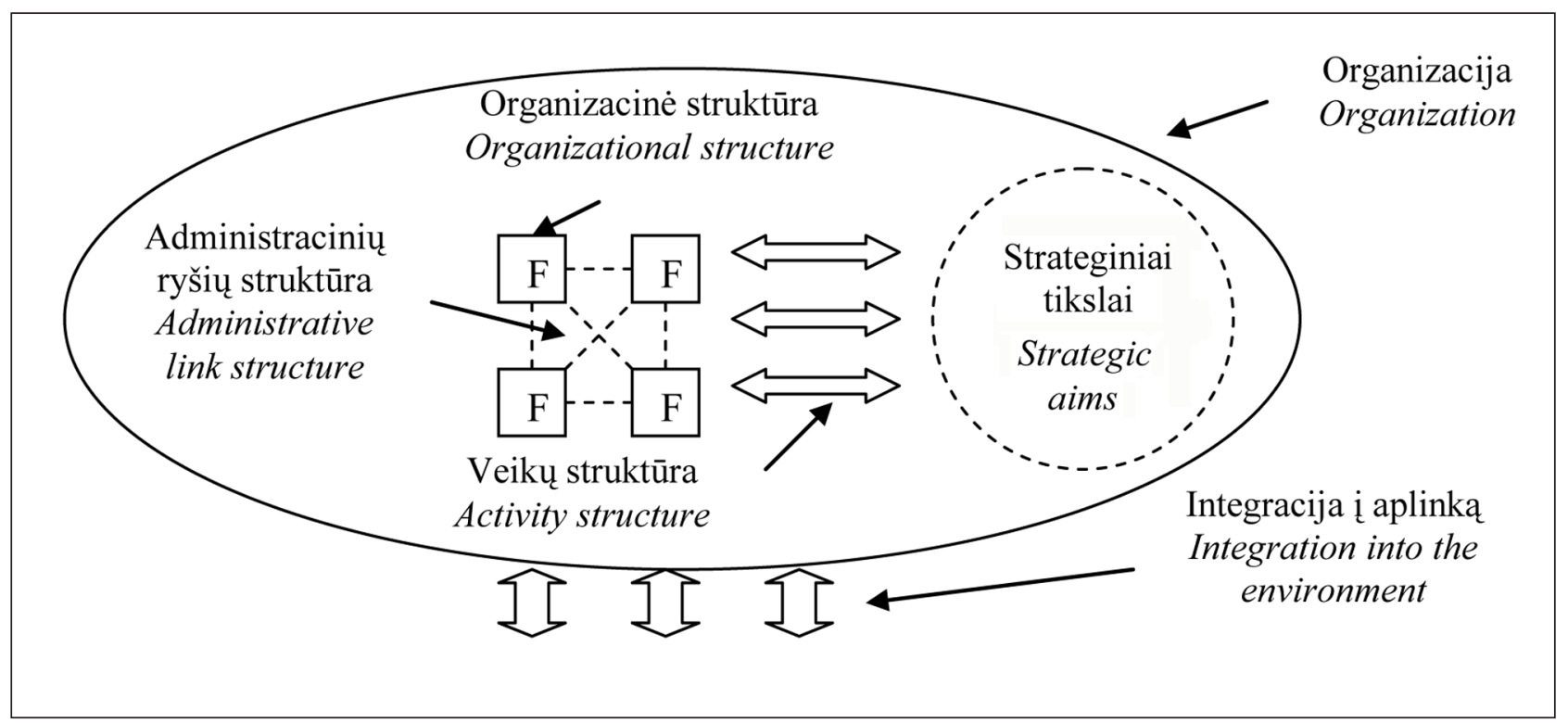

2 pav. Darbo vieta organizacijos veikos ir vystymo struktūroje (parengta autoriaus)

Fig. 2. Work places in the organization activities and development structure (prepared by the author) 
plètros galimybes analizuoja Karjeros plètros teorija (Brown, 2002; Career Development Theory...) bei Karjeros plètros ir sistemų teorija (Patton ir kt., 2006). Išskiriami du teorijų tipai:

- struktūrinès teorijos, susijusios su darbuotojų individualių gebejimų ir profesinių igūdžių ugdymu, grindžiamu žiniomis ir igūdžiais atlikti tam tikrus darbus derinant specialybès žinias ir profesinius igūdžius;

- vystymo teorijos, susijusios su žmogaus ugdymu visą gyvenimą, grindžiamu visuminio požiūrio formavimu, gebejjimu prisitaikyti prie pokyčių bei integracija ị aplinką.

Darbo jègos ugdymas - tai viena iš prielaidų didinti darbo efektyvumą, kurti pridedamąją vertę, kurią lemia tam tikras darbo našumas, igalinantis darbo jẻgą sukurti didesnę vertę nei jos pačios vertè. Tačiau darbo jègos pridètinę vertę lemia ne jos pati vertè, bet jos dèka sukurtas produktas, kuris užtikrina organizacijos veiklos funkcionavimą ir perspektyvas. Tad darbo vietų vystymas grindžiamas imonès ekonominès-gamybinès veiklos rezultatyvu$\mathrm{mu}$, kuris kokybinę išraišką igauna produkavimo ciklo procese (ištekliai - žaliava - gaminys - prekè - pajamos - investicijos) sukuriant pridètinę vertę, produktą paverčiant pelningu. Produkavimo ciklas rodo, kad veiklos rezultatyvumo rodiklis - poveikio veiklų (gavybos, perdirbimo, rinkodaros, prekybos ir finansų) dèka sukurta pridedamoji verté, formuojanti investicijų sistemą (Pilipavičius, 2010). Siekiant užtikrinti produkavimo proceso funkcionavimą, investicijos turi būti orientuotos $\mathfrak{i}$ nuolatinị išteklių atnaujinimą, $\dot{t}$ pokyti organizuojančias veiklas ir $\mathfrak{i}$ pridètinès vertès kūrimą. Produkavimo proceso funkcionavimo užtikrinimas pažymi organizacijos gyvybingumą, kaip vieną iš konkurencingumo elementų. Konkurencingumo formavimo ideja - didinti esamos rinkos dali ir gerinti poziciją esamoje šakos struktūroje bei rasti tinkamiausią būdą, padedantị organizacijai pasiekti geriausių rezultatų didinant bendrą savo vertę. Todèl greta gyvybingumo konkurencingumo elementu reiškiasi integralumas, kaip ryšys tarp kooperacijos ir bendradarbiavimo veiksmų, siekiant ịvairių sektorių veiklas integruoti $\mathfrak{i}$ bendrą visumą. Pastaruoju metu konkurencingumo parametrais pradeda reikštis ne tik nuolatinio funkcionavimo užtikrinimas (garantuojantis gy- vybingumą) ir veiklos integralumas (siekiantis būklès pagerinimo), bet ir konkurencija dèl ateities, kurią lemia verslumas.

Daugelis šių klausimų nagrinëjami mokymosi visą gyvenimą idejjos požiūriu. Mokymasis visą gyvenimą, R. Rinne (2003) įsitikinimu, tai:

- valstybès vadovaujamas mokymosi visą gyvenimą modelis;

- socialinès partnerystès modelis;

- rinka pagrịstas modelis.

Europos komisijos dokumente (Implementation Lifelong..., 2003) nurodoma, kad tai:

- gerai išvystyta nuo lopšio iki karsto mokymosi visą gyvenimą kultūra, palaikoma plačių visuomenès sluoksnių ir pasižyminti aktyviu piliečių dalyvavimu;

- labiau i isidarbinimą nukreiptas požiūris, linkstantis ị tęstinị mokymąsi prisitaikant prie besikeičiančių gamybos procesų ir struktūrų;

- susijęs su visuomenès modernizacija ir ekonomika, siekiama pakeisti tradicines nuostatas apie gyvenimo dalinimą $\mathfrak{i}$ atskiras mokymosi fazes;

- socialinès priklausomybès, sanglaudos požiūris, nukreiptas ị tuos, kurių pirminè patirtis švietimo sistemoje buvo nesékminga ar neatitinka šiuolaikinių pasaulinių nuostatų.

Mokymąsi visą gyvenimą P. Senge (1990); M. Pedler ir kt. (1998) sieja su besimokančios organizacijos ideja. Besimokančios organizacijos idejja yra pripažinimas ir reakcija ì bendradarbiavimą, grindžiamą individualiu, organizaciniu ir bendruomeniniu mokymusi. Besimokančios organizacijos koncepcijos kontekste darbo vietų vystymas organizacijoje turi tiesioginę priklausomybę tarp investicijų, veiklos vystymo ir išteklių (3 pav.).

Tačiau tai tik vidiniai darbo vietų vystymą organizacijoje lemiantys veiksniai. Organizacijos vystymas tiesiogiai susijęs su ekonomine veikla, kuri užtikrina darbo jègos užimtumą darbo rinkoje, kurią veikia ir išoriniai veiksniai: politika, teisinè ir švietimo sistema, rinka, infrastruktūra, vietos ištekliai, mentalumas, vertybès ir pan. (4 pav.).

Šiuolaikinis verslas peržengia ekonominès imties ribą. Vystant organizaciją privalu atsisakyti griežtos orientacijos tik $\mathfrak{i}$ vieną išteklių - finansus, būtina jivesti daugelị skirtingu operatyviniu sistemų, jungiančių socialinius, kultūrinius, ekonominius, veiklinius, intelektualinius, ekologinius ir pan. veiksnius. 
Organizacijos vystymo laukas / Organization development field

\begin{tabular}{|c|c|c|}
\hline $\begin{array}{l}\text { Veiklos vystymo kryptys } \\
\text { Activity development direction } \\
\text { - gyvybingumas } \\
\text { vitality } \\
\text { - konkurencingumas } \\
\text { competitiveness } \\
\text { - verslumas } \\
\text { entrepreneurship } \\
\text { - integruotumas } \\
\text { integrity } \\
\text { - profesionalumas } \\
\text { nrofescionalism }\end{array}$ & $\begin{array}{l}\text { Darbo vietur } \\
\text { vystymas } \\
\text { Work places } \\
\text { development }\end{array}$ & 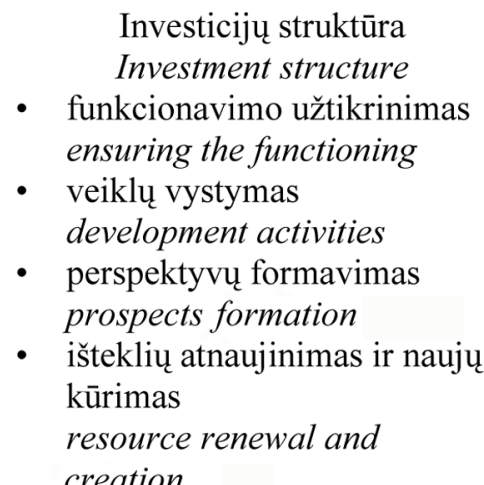 \\
\hline & \multirow{2}{*}{ 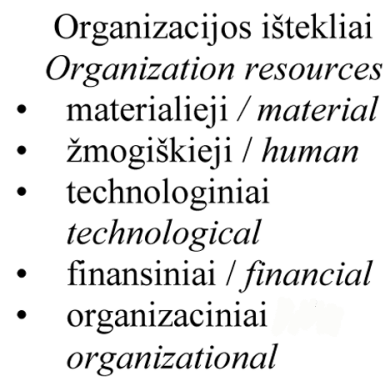 } & \\
\hline - & & \\
\hline
\end{tabular}

3 pav. Darbo vietų vystymo organizacijoje struktūra (parengta autoriaus)

Fig. 3. Structure of development of work places in the organization (prepared by the author)

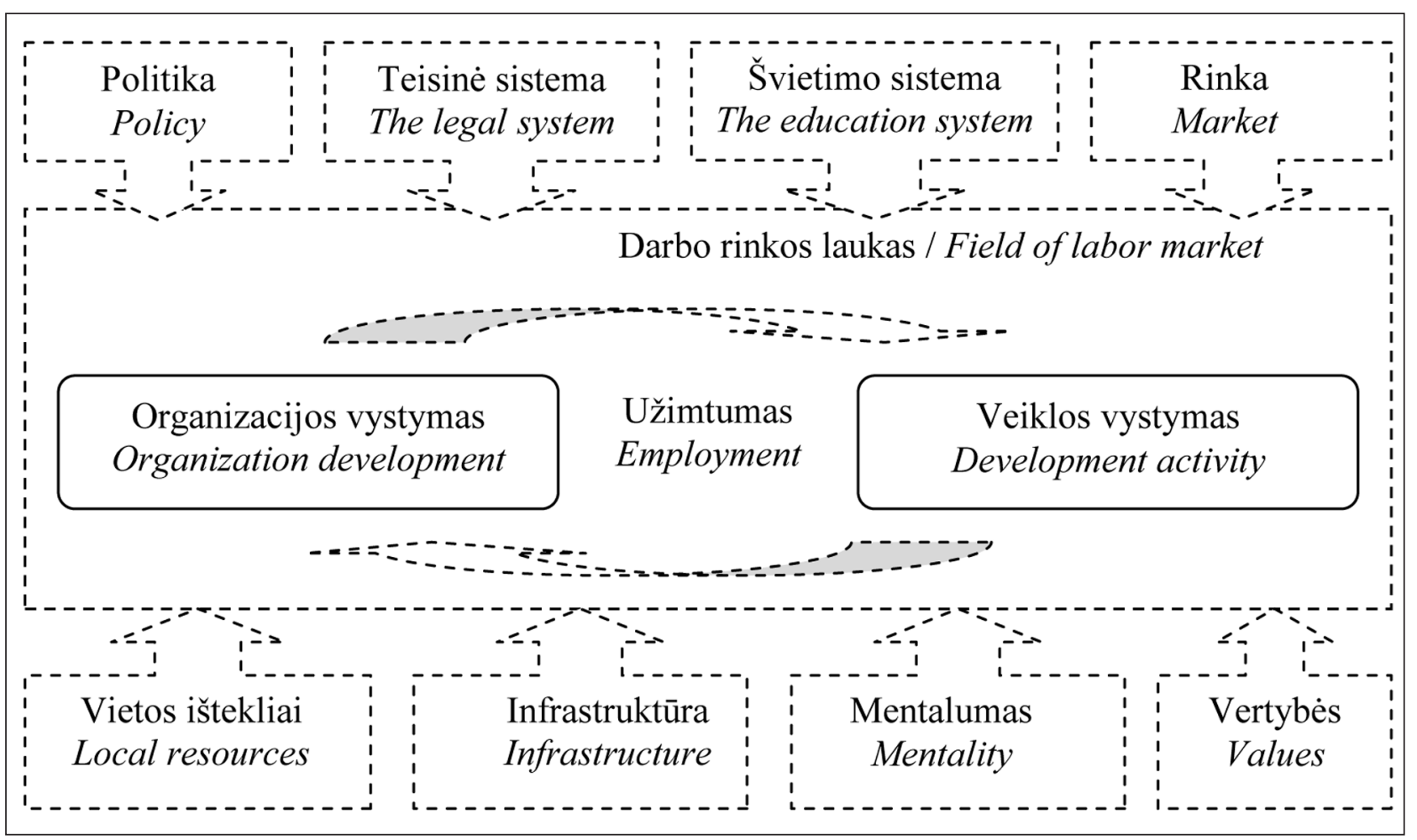

4 pav. Darbo vietų vystymo prielaidų struktūra (parengta autoriaus)

Fig. 4. Structure of assumptions for work places development (prepared by the author) 
Teorinių darbo vietų vystymo aspektų analizė parodé, kad darbo vietų vystymui (priklausomam nuo vidinių ir išorinių veiksnių) turi ittakos organizacijos ir veiklos vystymas, lemiantis užimtumą darbo rinkoje. Tačiau ši analizè parode ir ką kitą - t. y., kad darbo vietų vystymas didžiąja dalimi siejamas tik su organizacijos veiklos plètra. Darbo vietų vystymą kaimiškuosiuose regionuose lemia ne tik organizacijų, bet ir teritorijų vystymas.

Darnaus ir subalansuoto darbo vietu vystymo kaimiškuose regionuose teorinis modelis

Kaimiškumas yra vienas iš pagrindinių ES regioninès politikos veiksnių. Taikant specialius indikatorius (OECD, 1994) yra įvertintas visų ES šalių (NUTS-2) ir jų regionų (NUTS-3) kaimiškumas, kuris skirstomas pagal regiono gyventoju tankumą, gyventojų miesto ir kaimo bendruomenėse santykị bei gyventojų užimtumo struktūrą ir žemès ūkio reikšmingumą (Kaimiškųjų vietovių..., 2006). Panašia metodika remiasi ir EUROSTAT'as. Jo naudojamas klasifikavimo būdas pagrịstas gyventojų tankumo ir papildytu gyventojų skaičiaus rodikliu.

Kaimiškumo vertinimas pagal gyventojų miesto ir kaimo bendruomenèse santykị labiausiai paplitęs regiono kaimiškumo indikatorius, kuris taikomas ir oficialioje EBPO regionų klasifikacijoje (NUTS 1, NUTS 2 ir NUTS 3), (OECD, 1994).

Lietuvos mokslininkų darbuose (Treinys, Baležentis, 1999; Čaplikas, 2003; Poviliūnas, 2003; Vanagas, 2003; Vaitiekūnas, 2006 ir kt.) kaimas apibūdinamas kaip gyvenamoji vietovè su nedidele gyventojų koncentracija, kaip visa valstybès teritorija, išskyrus miestus, kaip mikrosocialinè ir ekonominè sistema.

Kaimo apibūdinimo kriterijai leidžia išskirti dvi kaimiškųjų regionų charakteristikas - kaimiškumą ir agrariškumą. Kaimiškumas atspindi socialinę-kultūrinę, o agrariškumas - ekonominę-aplinkosauginę kaimiškosios vietovès būklès sanklodą.

Pastaruoju metu kaimiškujuc regionų plètra siejama su darniu kaimo vystymu, orientuotu $\mathfrak{i}$ kaimo gyventojų gyvenimo kokybès gerinimą, kaimo ūkinès ir socialinès infrastruktūros bei bendradarbiavimo ryšių tobulinimą, užimtumo ir užsièmimo didinimą, pilietiškumo ir tautiškumo ugdymą, kraštovaizdžio, etnokultūros ir gamtos paveldo apsaugą bei puoselèjimą išsaugant kaimo materialinị bei dvasinị paveldą ateinančioms kartoms ir t. t.

Racionalaus kaimo funkcionavimo tikslų bei mokslo ir technikos pažangos požiūriu (Kaimo bendruomenių..., 2004) darni kaimo plètra apibréžiama kaip ekonominiai, socialiniai, kultūriniai ir aplinkosauginiai kiekybiniai bei kokybiniai pokyčiai.

Darnios kaimo pletros principai atspindi ir Nacionalinio saugumo strategiją, kur aplinkos ir kultūros paveldo apsauga bei socialinis ir ekonominis saugumas traktuojamas kaip nacionalinio saugumo politikos prioritetai (Nacionalinio saugumo..., 2002). Tuomet darnus kaimiškųjų regionų vystymas privalo atsispindèti ne tik vietos ir regiono, bet ir valstybingumo sanklodoje.

Teorinių darbo vietų vystymo prielaidų analizè parodé, kad darbo vietų vystymas organizacijos lygmeniu didžiąja dalimi tinka miesto vietovei, kur didelè gyventojų koncentracija, ne tiek svarbus gyventojų užimtumo lygis, bedarbysté, demografiniai rodikliai, atstumas iki darboviečių ir pan. Kaimiškųjų vietovių požiūriu, tai turi didelès reikšmès. Todèl darnus darbo vietų vystymas kaimiškose vietovèse priklauso ir nuo organizacijų vystymo, ir nuo teritorinès plètros. Jei darbo vietas vystant organizacijų lygmeniu pagrindinè varomoji jèga yra ekonominè veikla, didinanti užimtumą, tai teritoriniu atžvilgiu labai svarbų vaidmenị vaidina ir socialinè veikla, orientuota ił užsièmimo susiorganizavimą. Šiuo požiūriu darbo vietų vystymą kaimo vietovėse akivaizdžiai lemia ne tik kaimo teritorijai priskirti veiksniai, tačiau ir savivalda, kaip gyventojų ìsipareigojimas ir atsakomybė už gyvenamosios vietovès perspektyvas ir ateiti.

Darnus darbo vietų vystymas kaimiškuosiuose regionuose priklauso ne vien nuo užimtumo didinimo, veikiančio darbo rinkos formavimą, bet ir nuo teritorinès plètros, kuri jungia $\mathfrak{t}$ visumą ekonominius, socialinius, aplinkosauginius ir kultūrinius veiksnius, kai centruojančia ašimi tampa kaimiškųjų regionų vystymas, orientuotas i organizacijų veiklos plètrą ir savivaldos stiprinimą kaimiškoje vietoveje ( 5 pav.).

Darnus kaimiškųjų regionų vystymas, teikiamas programiniuose ir strateginiuose dokumentuose, pasižymi bendromis nuostatomis, tinkančiomis bet kuriai kaimiškajai vietovei. Tačiau kaimo gyvenamosios vietovès nèra tapačios viena kitai. 
Išoriniai veiksniai, lemiantys vystymą / External factors influencing the development:

Politika / Policy; Teisine sistema / The legal system; Švietimo sistema / The education system; Rinka / Market

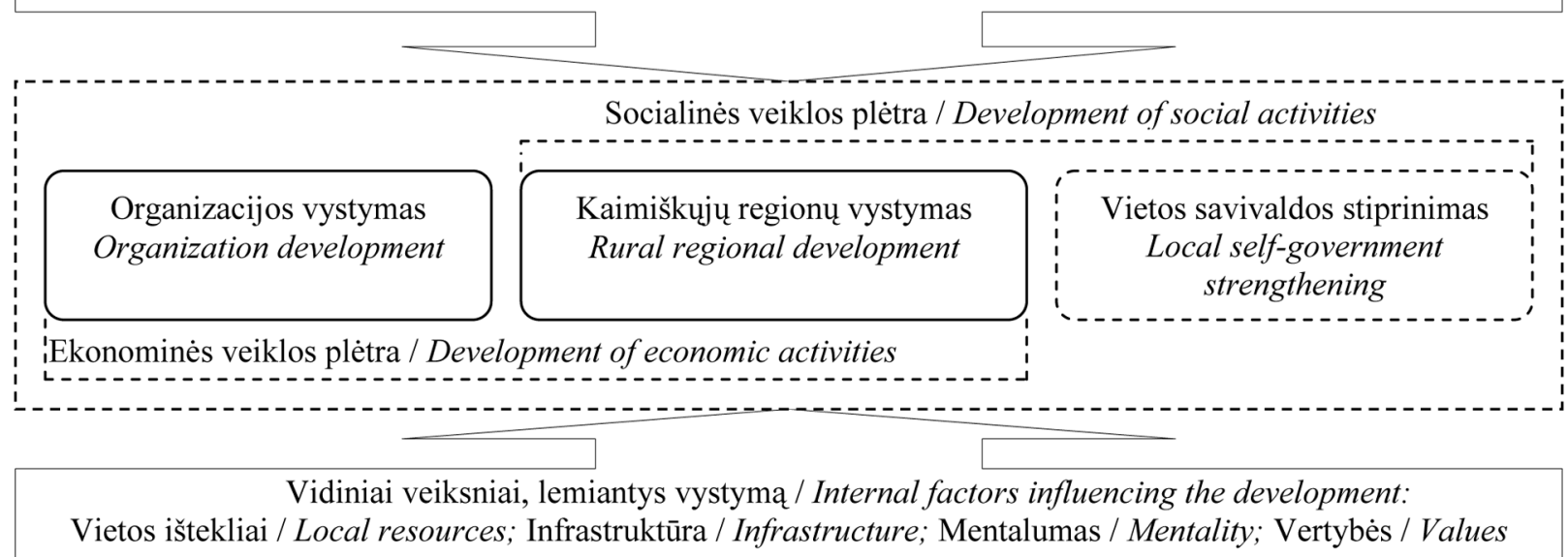

5 pav. Darnaus darbo vietų vystymo kaimiškuose regionuose koncepcinis modelis (parengta autoriaus)

Fig. 5. A conceptual model of sustainable work places development in rural areas (prepared by the author)

Siekiant darnaus darbo vietu vystymo kaimiškuose regionuose, būtina ìvertinti kaimo vietovių specifiką (konkretaus regiono kaimui priskirtinų požymių požiūriu) bei parengti kaimiškųjų vietovių tipologiją ir plètros scenarijus.

\section{IŠVADOS}

1. Teorinių darbo vietų vystymo prielaidų, kurias sudaro organizacijos ir veiklos vystymas, analize parodè, kad iki šiol darbo vietų kūrimas grindžiamas industrinès gamybos rinkos ekonomikos dèsniais, organizacijos vystymu ir veiklos integravimu $\mathfrak{i}$ aplinką. Darnų darbo vietų vystymą kaimiškuosiuose regionuose lemia ne tik organizacijų vystymas ir integracija $\mathfrak{i}$ aplinką, bet ir teritorijos vystymas. Todèl darnų darbo vietų vystymą kaimiškuose regionuose lemia ekonominès ir socialinès veiklos plètra vystant organizacijas ir kaimo vietoves bei stiprinant vietos savivaldą kaime.

2. Kadangi darnus darbo vietų vystymas teritoriniu požiūriu iš principo neanalizuotas, todèl parengtame koncepciniame darnaus darbo vietu vystymo kaimiškuose regionuose medelyje pažymètos tik objektų - organizacijų ir kaimiškųjų regionų - vystymo bei savivaldos stiprinimo kaimo vietovèse vietos, reikalaujančios gilesnès, išsamesnès analizès ir sisteminių tyrimų.

3. Lietuvoje parengta ir rengiama daug strateginių dokumentų, leidusių integruotis ị Europos Sąjungos erdvę bei sudarančiu galimybę orientuotis ES ateities tendencijose. Tačiau tai tik plètros kelio ženklai, perspektyvos gairèmis nužymètas pagrindinis kelias. Kol kas dar neaiški kaimo paskirtis (plačiaja prasme) Lietuvoje ir koks Lietuvos kaimas turi tapti ateityje. Siekiant darnaus darbo vietų vystymo kaimiškuose regionuose, būtina parengti Lietuvos kaimo vietovių vystymo koncepciją, kuri sujungtų ateities perspektyvas ir istorinį-kultūrinị kontekstą.

Gauta 20120206

Priimta 20121108

\section{LITERATŪRA}

1. Aleksandravičius A., Atkočiūnienè V., Brazienè R., Bartkutė D., Lamanauskas A., Senkutė L., Petkevičiūtè V., Seškovas A. 2004. Kaimo bendruomeniu plètra. Kolektyvine monografija. Kaunas: Akademija.

2. Aleksandravičius A. 2010. Kaimo vietovių vystymosi perspektyvos ES ir Lietuvoje po 2013 metu. Lietuvos kaimo vietovių konkurencingumo stiprinimas: geroji patirtis. Straipsniu rinkinys, 4-oji moksline - praktiné konferencija. Akademija. 
3. Baležentis A., Baležentis T. 2010. Europos Sąungos valstybių narių kaimo darnaus vystymo vertinimas. Vadybos mokslas ir studijos - kaimo verslu ir ju infrastruktūros plètrai = Management Theory and Studies for Rural Business and Infrastructure Development: mokslo darbai. Lietuvos žemès ùkio universitetas. Nr. 23(4). P. 16-25.

4. Bivainis E., Tamošiūnas T. 2007. Darnus regionų vystymasis: teorinis diskursas. Ekonomika ir vadyba: aktualijos ir perspektyvos. Nr. 1(8). P. 30-36.

5. Bosworth G. 2006. Counterurbanisation and Job Creation: Entrepreneurial In-Migration and Rural Economic Development. Centre for Rural Economy Discussion Paper Series. No. 4. 16 p. [žiūrèta 2011-10-20]. Prieiga per internetą: http:// www.ncl.ac.uk/cre/publish/discussionpapers/ pdfs/dp4.pdf

6. Brundtland Report [žiūrèta 2011-04-05]. Prieiga per internetą: http://translate.google.lt/translat e?hl=lt\&langpair=en\%7Clt\&u=http://www.ace. mmu.ac.uk/eae/sustainability/older/Brundtland_ Report.html

7. Brown D. 2002. Career Choice and Development, 4th Edition. San Francisco: Jossey-Bass.

8. Brandbury H., Clair J. A. 1999. Promoting Sustainable Organizations with Sweden's Natural Step. Academy of Management Executive. Vol. 13. No. 4. P. 63-74.

9. Brandbury H. 2000. On the Plural Attentions Necessary for Catalyzing and Implementing Sustainable Development. Reflections. Vol. 1. No. 4. P. 13-21.

10. Career Development Theory and Process [žiūrèta 2011-10-20]. Prieiga per internetą:http:// www.virtualhabitats.com/Students/CareerCounselorWebquest/Career\%20Development\%20Theory.pdf

11. Ciani A. 1998. The Integrated and Sustainable Rural Development Strategy. The Perspectives for the Center European Countries. Yugoslavia.

12. Čepinskis J., Smilga V. 2002. Strateginis subalansuotas plètros valdymas. Organizaciju vadyba: sisteminiai tyrimai. Nr. 22. P. 55.

13. Čaplikas J., Michailovaitè N. 2003. Miesto ir kaimo ekonominè bei socialinė sąveika Lietuvos regionuose. Vagos: LŽŪU mokslo darbai. Nr. 61(14). P. 38-43.

14. Čiegis R., Ramanauskienè J., Martinkus B. 2009. Concept of Sustainable Development and its Use for Sustainability Scenarios. Inžinerinè ekonomi$k a-$ Engineering Economics. Nr. 2. P. 28-37.

15. Darbotvarké 21. Jungtinių Tautų Rio veiksmų programa. 2001. REC biuras Lietuvoje. Rubrika „Darnus vystymasis“ [žiūrèta 2011-10-20]. Prieiga per internetą: http://www.am.lt/VI/index. php\#a/1128

16. Frascati vadovas [žiūrèta 2011-12-20]. Prieiga per internetą: http://internet.ktu.lt/lt/mokslas/Frascati_ vadovas.pdf
17. Ghai D. 2006. Decent Work: Objectives and Strategies. Genève: International Institute for Labour Studies and International Labour Office. 241 p. [žiūrèta 2011-07-07]. Prieiga per internetą: http://www.oit.org/public/english/bureau/inst/ download/decentghai.pdf

18. Gercheva D. 2005. Local Sustainable Development Planning: Manual for a Local Sustainable Development Strategy Formulation [žiūrèta 2011-02-20]. Prieiga per internetą: http://www.capacity.undp. org $/$ index.cfm? module $=$ Library\&page $=$ Documen t\&DocumentID $=5193$

19. Gruževskis B., Gražulis V. 2008. Lietuvos darbo rinkos politikos raidos ypatumai: situacijos analizè ir raidos perspektyvos. Viešoji politika ir administravimas. Mykolo Romerio universitetas. Nr. 26.

20. Hasna A. M. 2007. Dimensions of Sustainability. Journal of Engineering for Sustainable Development. No. 2(1). P. 47-57.

21. Implementing Lifelong Learning Strategies in Europe: Progress Report on the Follow-up to the Council Resolution of 2002. EU and ETFA/EEA Countries. Brussels: European Commision.

22. Young M. D. 1991. Sustainable Investment and Resource Use: Equity, Environmental Integrity and Economics Efficiency. Man and the Environment Series. Paris. Vol. 9. P. 49-62.

23. Jones P., Osterweil C., Whitehead D. 1996. Delivering Exceptional Performance: Aligning the Potential of Organizations, Teams and Individuals. London: Pitman.

24. Juknys R. 2007. Darnus vystymasis Lietuvoje: dabartis ir perspektyvos [interaktyvus]. Kaunas: VDU [žiūrèta 2011-09-19]. Prieiga per internetą: http:// www.achemosgrupe.lt/media/pdf/2-R-Juknys.pdf

25. Kaimiškuju vietoviu įtaka Lietuvos regionu gyvenimo kokybei ir sanglaudai. 2006. Mokslinių tyrimų darbo ataskaita, registracijos Nr. M-06009, sutarties Nr. P-33/06. Kaunas: LŽŪU.

26. Kaimo bendruomenių plètra. 2004. Kolektyvinè monografija. Kaunas.

27. Krugman P. R., Obstfeld M. 1991. International Economics: Theory and Policy.

28. Lietuvos kaimo pletros programa 2007-2013 metams [interaktyvus] [žiūrèta 2011-12-20]. Prieiga per internetą: http://www.nma.lt/index.php?1026816762

29. Mačys G. 2006. Regionu ekonomika, politika ir valdymas Lietuvoje. Vilnius: Mykolo Romerio universiteto Leidybos centras.

30. Mayer F. 1991. The Regulation of Part-Time Work: A Comparative Study of Six EC-Countries. Discussions Paper FS I 91-9. Berlin.

31. McConnell C. R., Brue S. L. 1986. Contemporary Labor Economics. New York: McGraw Hill Book Company.

32. Martinkus B., Beržinskienè D. 2007. Darbo rinkos rodiklių pokyčiu identifikavimas. Taikomoji ekonomika: sisteminiai tyrimai. 
33. Martinkus B., Beržinskienè D. 2005. Lietuvos gyventoju užimtumo ekonominiai aspektai. Kaunas: Technologija.

34. Martinkus B., Savanevičienė A. 1996. Darbo ekonomika. Kaunas: Technologija.

35. Moskvina J. 2008. Aktyvios darbo rinkos politikos priemonių vertinimas. Probleminiai klausimai. Filosofija. Sociologija. T. 19. Nr. 4. P. 1-9 [žiūrèta 2011-12-02]. Prieiga per internetą: http://www. minfolit.lt/arch/16501/16696.pdf

36. Nacionaline darnaus vystymosi strategija. Lietuvos Respublikos Vyriausybės 2009 m. rugsèjo $16 \mathrm{~d}$. nutarimo Nr. 1247 redakcija [žiūrèta 2012-01-05]. Prieiga per internetą: http://www.smm.lt/veikla/ docs/dv_svietimas/0.816819001255418152.pdf

37. Nacionalinio saugumo strategija. 2002. Lietuvos Respublikos Seimo nutarimas Nr. IX-907, 200205-28. Valstybés Žinios. Nr. 56-2233.

38. Nattrass B., Altomare M. 1999. The Natural Step for Business: Wealth, Ecology, and the Evolutionary Corporation. Gabriola Island, British Columbia, Canada: New Society Publishers.

39. Navickas V., Paulavičius K. 1999. Darbo rinka. Teorija ir valstybes politika. Vilnius.

40. OECD 1994. Creating Rural Indicators for Shaping Territorial Policy. Paris: Organisation for Economic Co-operation and Development.

41. Olborgo chartija [žiūrèta 2011-01-05]. Prieiga per internetą: http://sustainable-cities.eu/upload/pdf_ files/ac_lithuanian.pdf

42. Ott K. 2003. The Case for Strong Sustainability. In: K. Ott, P. Thapa (eds.). Greifswald's Environmental Ethics. Greifswald: Steinbecker Verlag Ulrich Rose.

43. Patton W., McMahon M. 2006. Career Development and Systems Theory. Connecting and Practice.

44. Pedler M., Aspinwall K. 1998. A Concise Guide to the Learning Organization. London: Lemos \& Crane.

45. Philip R., Berke C., Marija M. C. 2000. Are we planning for sustainable development? [žiūrèta 2011-1220]. Prieiga per internetą: http://www.planning.org/ audioconference/LEEDN/pdf/JAPA0100.pdf

46. Pilipavičius V. 2010. Bendruomeninè veikla ir kaimo vietovių konkurencingumo stiprinimas.
Ekonomikos ir vadybos fakulteto 2009 metu moksliniu tyrimy rezultatai: mokslines konferencijos straipsniu rinkinys. Nr. 1(6). P. 84-90.

47. Rinne R. 2003. Besimokančios visuomenès link. Profesinis rengimas. Tyrimai ir realijos. Nr. 6. P. 94-104.

48. Simanavičienė A., Užkurytė L. 2009. Pokyčiai darbo rinkoje ekonominio nuosmukio metu: Lietuvos atvejis. Ekonomika ir vadyba. Nr. 14. P. 940-946.

49. Skydan O. 2008. Sustainable Rural Development as a Priority of Agrarian Policy. Management Theory \& Studies for Rural Business \& Infrastructure Development. No. 15(4). P. 49-65.

50. Treinys M., Balažentis A. 1999. Kai kurie teoriniai ir metodologiniai kaimo plètros strategijos klausimai. Lietuvos kaimo pletros politika ir mokslo uždaviniai. Vilnius.

51. Vaznonis V., Čiūtaitè D. 2010. Kaimo vietovių ekonominio konkurencingumo ir vietos gyventojų verslumo sąsajos. Vadybos mokslas ir studijos - kaimo verslu ir ju infrastruktūros plètrai. Management Theory and Studies for Rural Business and Infrastructure Development: mokslo darbai. Lietuvos žemès ūkio universitetas. Nr. 22(3). P. 181-189. [Business Source Complete].

52. Vitunskienè V. 2009. Kaimo plètros 20042006 metu plano priemonių igyvendinimo bendrieji efektai: galutinio (ex-post) ivvertinimo rezultatai. Ekonomikos ir vadybos fakulteto 2008 metu moksliniu tyrimu rezultatai: mokslinès konferencijos straipsniu rinkinys [žiūrèta 2011-12-12]. Prieiga per internetą: http://www.lzuu.lt/mtr/

53. Wonnacott P., Wonnacott R. 1994. Makroekonomika. Kaunas: Litterae Universitatis.

54. Ziminienė N. 2008. Nacionalinès Lisabonos strategijos igyvendinimo programos tikslų užimtumo srityje pasiekimo vertinimas: magistro darbas. Vilnius: MRU.

55. Žukovskis J. 2009. Kaimo plètros tikslų ir uždavinių raida. Management Theory \& Studies for Rural Business \& Infrastructure Development. Nr. 19(4). P. 103-108. 


\section{Vytautas Pilipavičius}

\section{THEORETICAL ASSUMPTIONS OF SUSTAINABLE} WORK PLACES DEVELOPMENT IN RURAL AREAS

\section{Sum mary}

Work places development in rural areas is one of the most important tasks for the European Union and Lithuania in implementation of agricultural and rural development policies and its priorities.

Today, a significant role in the Lithuanian rural development process is given to the development of rural regions, based on coherent and sustainable work places creation in rural areas.

The research problems were analyzed in the article as the following questions: What are the theoretical assumptions of work places development? What makes sustainable and balanced work places development in rural areas?

The concepts of sustainable development, an overview of the theoretical aspects of work places development and analysis of sustainable work places development in rural areas are presented in the article. Based on the analysis, the conceptual model of sustainable work places development in rural regions was developed.

The analysis has shown that work places development is based on the principles of industrial market economies, organization and its business development, integration into environmental dependence. Not only organization development and its integration into environment, but also the development of the territories influences the development of work places in rural areas. Therefore, sustainable development of work places in rural areas leads to economic and social development of organizations and local self-government, rural development direction in rural areas.

The research was financed by the support from the Research Council of Lithuania according to the National Research Programme "Social Challenges for National Security".

Key words: sustainable development, work places development, rural regional development 